\title{
Internalization Of Islamic Values In Science Education
}

\author{
Abdul Aziz bin Mustamin ${ }^{1}$, Bevo Wahono ${ }^{2}$ \\ ${ }^{1}$ Institut Agama Islam Negeri Bengkulu, Indonesia \\ Jl. Raden Fatah Kec. Selebar Kota Bengkulu, Bengkulu 38211 \\ ${ }^{2}$ Graduate Institute of Science Education, National Taiwan Normal University, Taiwan \\ No. 162, Section 1, Heping East Road, Da'an District, Taipei City, Taiwan 106
}

Received: January $3^{\text {rd }}, 2020$

Coressponding Author E-mail:

1 abdulazizm@iainbengkulu.ac.id

2bevo.fkip@unej.ac.id

\section{Abstrak}

The study aims to increase the relative contribution of science learning to the achievement of national education goals. Internalizing the value of monotheism in scientific material will not reduce the level of scientific scholarship itself. This research is a qualitative study that is a literature study (library research) that uses books and other literature as the main object. In fact, these studies can improve the quality of science material. Science as a means to develop cognitive potential, science can also grow the potential of conscience (affective). This scientific material will be able to instill confidence in everything that exists in nature. Everything that is essentially created by God, Almighty God. This belief can drive against beliefs about submission, characteristics, and order of things that Allah created (sunnatullah), so that humans can learn them. All this will enable the growth of a positive attitude, the awe of the greatness, power, and love of God, a motivation to give thanks, increase faith and devotion to Allah Almighty. Internalization of the value of monotheism in science material can be done through the disclosure of values/wisdom/meaning/nature of the scientific material based on Islamic values.

Keywords: Islamic Values; Science Education; Internalization

How to cite this article :

Mustamin, A.A.B., \& Wahono, B. (2020). Internalization Of Islamic Values In Science Education. IJIS Edu : Indonesian Journal of Integrated Science Education, 2(1), 75-80. doi:http://dx.doi.org/10.29300/ijisedu.v2i1.2671 


\section{INTRODUCTION}

In 1945 Constitution Article 31, national education aims toincrease faith and devotion to God Almighty and noble character in the context of intellectual life of the nation. The law indicates the meaning that education in Indonesia is essentially to form qualified and qualified Indonesian peoplewell. According to UUSPN No. 2 of 1989, ualified Indonesian people, namely people who have faith and piety towards God Almighty, virtuous character, personality, discipline, hard working, tough, responsible, independent, intelligent and skilled, and healthy physically and spiritually, love for homeland and will of the nation and state and have high social solidarity.

Explanation of the purpose of further education is stated in UUSPN no. 20 of 2003 article (1), that education is a conscious and planned effort to create an atmosphere of learning and learning process so that students actively develop their potential to have religious spiritual strength, self-control, personality, intelligence, noble character, and the necessary skills himself and the community. UUSPN No. 20 of 2003 Article (3), national education functions to develop capabilities and shape the dignified character and civilization of the nation in the context of educating the life of the nation, aiming at developing the potential of students to become human beings who believe in and have faith in God Almighty, have noble, healthy morals , knowledgeable, competent, creative, independent, and become democratic and responsible citizens.

Indonesia has long held education even long before independence, but the level of achievement of national education goals as stated in the law is still far from expectations. The failure to achieve this goal, especially in terms of faith, piety and morals, may even get worse. Moral decadence occurs in all sectors. Environmental destruction, deforestation, environmental pollution (water, air and soil) occur everywhere. Likewise, the abuse of the use of chemicals: formaldehyde, borax, dyes and additives, alcohol and drug consumption among students which triggered other crimes, bomb terror to the detonation of suicide bombings is increasingly widespread.This fact shows there has been a missmatch in the world of education and learning in Indonesia and even throughout the world. This is thought to be in large part because our education has not developed the potential of conscience (affective), the development of cognitive abilities or highly developed brain is not guarded by the development of conscience so it will be potentially destructive. This assumption is in line with the opinion of experts who say that the damage occurred because of the lack of emphasis on moral problems (Sauri, 2005), and the learning system in Indonesia is still only partial on cognitive aspects (Djahiri, 1996).

Science education is part of national education. Science education has the main goal to instill confidence in God Almighty based on the existence, beauty and regularity of His natural creations (Depdiknas, 2008: 377). This main goal is something that continues to be fought for through various strategies. One reason is how this very strong objective with the term and spirit of diversity will be achieved while the science taught from kindergarten to university level is Western heritage science that clearly separates or alienates from religion. Science in Indonesia should be a means of serving God to achieve world and hereafter happiness.

Basically there is nothing wrong with Western science that is scientific, because in essence everything belongs to God. Science that studies the universe belongs to Allah, signs of God's power (ayat kauniyah). Through verses kauniyah should be able to increase the faith of the verses qauliyah. This will only be achieved if: (1) motivation or intention to study science because of God; (2) science must be given meaning / value / wisdom from a religious point of view; (3) science must be grateful, that is, using science based on the consideration of being loved by God or not. For this reason, the value of rububiyah and uluhiyah's monotheism must be instilled in learning, especially through internalization in science teaching materials.In this paper, we will try to present several models of the internalization of Islamic values in science education in the hope that through scientific material will awaken the potential of conscience or affection for learners who will lead to increased faith and piety

\section{RESEARCH METHOD}

This research is a qualitative study that is a literature study (library research) which uses books and other literature as the main object (Hadi, 1995: 3). This type of research is qualitative, namely research that produces information in the form of notes and descriptive 
data contained in the text under study (Mantra, 2008: 30).

\section{RESULTS AND DISCUSSION}

In order to explore how Islamic values influence science, it is necessary to outline our 'working definition' of values for research purposes. Values have been described as a "....conception, explicit, or implicit of what an individual or a group regards as desirable...." (Guth and Tagiuri, 1965); a preference for "certain affairs over others (Hofstede 1981 p 19); and that which "... guide and direct our behaviour and affect our daily lived experiences" (Dolan, Garcia and Richley 2006). These are, however, thumbnail 'definitions' and as such, they are challenging to employ in a study which seeks not only to discover the existence of values but also their enactment within a cultural context. This challenging task is further compounded by Ali's reminder (2005) that values are often "confused with other related terms such as attitudes, beliefs, needs and norms".

Islamic civilization is the first civilization to integrate science and religion in an integrated way. As a result of the integration of this science and religion, Islamic civilization noted the rise of civilization which resulted in amazing scientific discoveries during the seven periods of Umayyad Daula, Abbasid Daula, and Daula Fathimiyah.

In Islam the combination of religion and science is not a strange thing, because Allah's command to Muhammad SAW as the last messenger, iqra or read / investigate (QS 96: 15), whereas at that time the holy book of the Koran 'Not yet there, only the verse was revealed. This means that the command to read / investigate also includes reading God's creations in the universe, now known as science. This belief was agreed upon by Muslim scientists from the past until now.

Basically all the holy books that Allah revealed to his messengers (the Qur'an which was revealed to the Prophet Muhammad, the Torah to the prophet Moses, the Gospel to the Prophet Jesus, the Psalms to the Prophet David) are qauliyah verses or verses written in Scripture. While that is implied in the universe of His creation are kauniyah verses. Both are beneficial to humans and are a harmonious and mutually reinforcing partner, it is impossible to contradict because it comes from the same source, namely God. One difference is the qauliyah verse is absolute truth. While the truth is relative verses kauniyyah. This is because the verse qauliyah is the direct word of Allah. However, in the verse qauliyah (al-Qur'an) apparently there is much talk about the kauniyyah verse. Even according to Shia Jauhari Thanthawi, professor at Cairo University (Hartono, 2010: 76) revealed that in the Qur'an (verses qauliyah) there are more than 750 verses of kauniyah while the verse about fiqh is only about 150 verses. This indicates how many links between the Kauniyyah verse and the Qauliyah verse. And how much the Koran expands about the universe is nothing but a study of science.

So basically, in the early days of the revival of the world of science begins with an intimate relationship between science and religion while in the revival of the West (after the Islamic state was conquered by the Mongol army from the East and the Crusaders from the West) the rise of science begins with an inharmonious relationship between science and religion .

Science education today in Indonesia is a legacy of Western colonialism. Education that separates science from religion has produced extraordinary advances in science and technology, but has not succeeded in bringing people to true happiness. This is indicated by the occurrence of moral decadence.

Awareness of the negative effects of the education system that separates religion from science has been widely recognized by various Muslim circles. In response to this, Islamic education institutions have emerged that are labeled integrated schools, superior, plus, Islamic colleges and universities. Some Muslim students and teachers have done someresearch on the integration of science and religion both at the level of preparing science teaching materials that are integrated with religion, as well as efforts towards equipping teachers' abilities to be able to integrate (Hartono, 2011: 76 and Rochman, 2010: 87). All this shows concern and responsibility as a Muslim academic community who have the belief of the importance of aligning or guiding science with religion, even though all are still on the level of seeking form. Basically, all this is an attempt to restore the integration of science and religion.

Religion that originates from revelation will play a role in providing direction, motivation and ensuring that science can function to provide goodness, benefit, spiritual well-being of humankind, valuable worship, embodiment of gratitude and means to increase faith and piety in order to serve God. Likewise, bringing science to 
religion within certain limits can provide benefits in enhancing a Muslim's faith through higher quality, not too dogmatic understanding and ways of religion. If this has been entrenched in the world of science education, it will be a guarantee of the achievement of the source of welfare / blessing of the birth and mind, the world and the hereafter. The main national education goals and science learning objectives can be achieved.

The rationale for the integration of religion and science, the nature of monotheism, monotheism and science. Etymologically, internalization shows a process. In the Indonesian language the suffix "isasi" means the process, so that internalization can be defined as a process (Ardiansyah, 2011: 40). In the Big Indonesian Dictionary, internalization is defined as appreciation, deepening, mastery in depth that takes place through fostering, guidance and so on (Big Indonesian Dictionary, 1989). Whereas in the Oxford dictionary. "Internal" means "of or in the inside" (Hornby et all, 1986) which means inside.

According to the Department of P \& K (2004) internalization is a process experienced by a person throughout his life, in terms of accepting and making a part of himself, various attitudes, ways to express feelings or emotions, fulfillment of desires, desires, passions or beliefs, norms and values -values as owned by other individuals in the group.

The process of internalization can go through various stages or methods. Some experts say that internalization is a potential affective world that occurs after going through the stages of acceptance, understanding, responding, and assessing. Internalization of values, as it teaches values, can be done by following the stages: orientation / information, giving examples and non-examples, practice / habituation or drill, reflection or feedback and follow-up and reinforcement.

According to Muhaimin (Ardiansyah, 2011: 57), there are three stages of occurrenceinternalization, namely: (1) the value transformation stage, this stage is a process carried out by educators in informing good and bad values. At this stage verbal communication only occurs between the educator and the students or foster children; (2) value transaction stage, a stage of value education by way of twoway communication, or interactions between students and educators that are reciprocal interactions; (3) the transinternalisation stage, this stage is far more profound than the transaction stage. At this stage not only is done by verbal communication but also mental attitude and personality. So, at this stage personality communication plays an active role.

There are several methods or strategies to internalize the methods that can be done. Murdiono (2010) revealed, that the strategy of internalizing religious values in learning includes modeling, actual problems in society, instilling contextual educative values, and strengthening moral values. The same thing was expressed by Simon, Howe, and Kirschenbaum (Wahab, 2007), that in internalizing moral values can be done with four approaches, namely the moral cultivation approach, the free value transmission approach, the exemplary approach, and the value clarification approach. Meanwhile, according to Fu'ad (in Jamaluddin, 2010) inculcation of the value of monotheism / creed can be done in various ways, including: analogies, wisdom, through stories, and dialogue through logical approaches.

Based on some of the references above, it can be concluded that internalization is a process of instilling values in depth so as to form personalities, become philosophies, strong beliefs and be the basis for perspective, thinking, acting and acting. Internalization occurs through various stages and can be done with various approachesor way.

Internalization of the value of monotheism in scientific material, is expected to arisebelief about everything created by God and not in vain, there is a belief about submission, characteristics and order of the things that Allah created (sunatullah), so that humans can learn it. All this will enable the growth of a positive attitude, awe / admiration for the greatness, power and compassion of God, a motivation to give thanks, increase faith and devotion to God Almighty as stipulated in the goals of national education.

enter the value of monotheism in science material, so science that was only scientific in nature can only develop cognitive potential into science that can also develop affective potential (conscience). This can be done by expressing the values / wisdom / meanings or moral messages of the science material based on the religious point of view. For example, when explaining the topic of water, it is not enough to explain that water is a chemical compound with the molecular formula $\mathrm{H} 2 \mathrm{O}$, but also explained that water is a gift given by God to humans to be used as a source of life for all His creatures both humans, 
plants and animals and also explained about the management and processing processes. This kind of presentation will have a very positive impact on student learning outcomes so students have the desire to see water as an economic source (business) and even allow students to value water in the sense of preserving and preserving it. This attitude is good enough to remind students about who bestows the water. Thus it is hoped that humans through this integrated education will benefit the world and the hereafter in accordance with the noble goals of national education. The key is that science material must not be released from religion.

Presenting a religious perspective on the topic of water throughinternalization of the value of monotheism, will produce students who have positive attitudes among them not arrogant because all the same are created from water, amazed at the greatness of God, feel given a lot of favors, which finally embarrassed to disobey Allah. From this attitude, it will grow gratitude and desire to use their knowledge with consideration of seeking God's blessing, desire to carry out other commands, and even then it is expected to increase faith and devotion to God as creator, preserver, loving and compassionate.

\section{CONCLUSION}

Basically, the internalization of the value of monotheism must be carried out on all scientific material. For science material that is related to religion either explicitly or implicitly, internalization can be done at the beginning, in the process and at the end of the discussion of science material. Internalization at the beginning is done to cultivate reading and studying religion (verses or hadith), arousing motivation, giving direction, a foundation in learning science. Internalization in the process of discussing scientific material is done through direct integration, by combining scientific and religious perspectives. Internalization of Islamic values at the end of the discussion of the material is intended so that through science material can raise awareness about grace and compassion, greatness and power, gratitude to God. Whereas for science material with no known connection to religion, internalization of the value of monotheism can only be done at the beginning and end without any integration process. in the beginning it was also done without having to read and study religion. For scientific material that is anomalous (like the case of water) and materials that are not favored, such as volcanoes, it is necessary to emphasize wisdom (God's destiny with all its wisdom). The success of internalizing Islamic values in science material or in science learning is largely determined by teacher factors. The teacher must be professional in scientific material and must understand about religion (the Qur'an and Hadith). The most important thing the teacher must be able to be a role model in moral issues (Moral to God, fellow human beings and the environment), so that the teacher himself canacting as a model. UIN / IAIN is an institution that allows printing teachers who have these abilities.

\section{REFERENCES}

Aditama, F. (2015). Efektivitas pembelajaran induktif berbantuan geogebra pada materi garis singgung persekutuan dua lingkaran di kelas VIII SMP Negeri 1 Surabaya. MATHEdunesa, 3(3).

Bagir, Z.A., Wahyudi, J., Anshori, A.(2005). Integrasi Ilmu dan Agama : Interpretasi dan Aksi. Bandung : Mizan

Billa, Mutamakkin, (2005) "Pemaknaan Teologis M. Fethullah Gulen tentang Relasi Agama dan Sains, Teosofi, Jurnal Tasawuf dan Pemikiran Islam, Volume 1 Nomor 2 2011. Fakultas Ushuluddin IAIN Sunan Ampel, Surabaya

Cantor, Geoffrey dan Chris Kenny, (2001) "Barbour's Fourfold Way: Problems With His Taxonomy of Science Religion Relationship", Zygon, Vol.36, No.4: 768769.

Clayton, Philip. (2003) "Perceiving God in the Lawfulness of Nature: Scientific and Religious Reflections", International Conference on "Religion \& Science in the Post-Colonial World", Yogyakarta: Center for Religious and Cross-cultural Studies UGM dan Templeton Foundation USA, 25

Departemen Agama. (1989). Al-Qur'an dan terjemahannya. Jakarta : Departemen Agama RI 
Djahiri, A.K. (1996). Menelusuri Dunia Afektif : Pendidikan dan Moral. Bandung : Lab Pengajaran PMP IKIP Bandung.

Hartono. (2011). Pengembangan Model Pendidikan Nilai Dalam Pembelajaran Iintegrasi Sains dan Agama di MA Darul Ulum Jombang. Desertasi Doktor SPs UPI Bandung :

Khasanah, N., Saiidan, S., Sutarno, S., Prayitno, B. A., \& Walid, A. (2019). Critical Thinking Ability and Student's Personal Religious Beliefs: An Analysis of DBUS Model Implementation. Tadris: Jurnal Keguruan dan Ilmu Tarbiyah, 4(1), 41-49.

Kusnadi. (2000). Pengembangan Pembelajaran Integrasi Nilai-Nilai Tauhid Dalam Pengajaran Geografi (Penelitian Tindakan Di Kelas I SMU 19 Kotamadya Bandung). Tesis PPS UPI Bandung : tidak diterbitkan.

Hidayatullah, Syarif. (2017), "Relasi Agama Dan Sains Dalam Pandangan Mehdi Golshani, Jurnal Filsafat, Vol. 27, No. 1,

Nugraha, Wahyu. (2003) “Teologi Kristen dalam Konteks Sains: Kajian Kitis atas Gagasan Arthur Peacocke", Relief, Volume 1, Nomor 1: 23-42.

Riduansyah. (2000). Penerapan Model Pembelajaran Terpadu Antara Biologi Dan Imtaq Untuk Meningkatkan Hasil Belajar Siswa MA. Tesis pada FPS IKIP Bandung : tidak diterbitkan.

Romadlon, M. (2000). Pembelajaran Kimia Sub Bahan Kajian Zat Aditif Pada Makanan Yang Terintegrasi Nilai-Nilai Agama.Tesis FPS UPI 